\title{
The Free Movement of Persons in the Eurasian Economic Union - between Civis Eurasiaticus and Homo Oeconomicus
}

\author{
Benedikt Pirker and Kirill Entin*
}

Introduction

Few commentators would suggest that the Eurasian Economic Union (EAEU) is in any way a European Union (EU) "in the making". Nonetheless, as a regional integration project, the EAEU faces many challenges similar to those faced by the EU, and much can be learned from an informed comparison of the two organisations. The present chapter examines the state of the right to free movement of persons in the Eurasian Economic Union. No formal EAEU citizenship exists which would be comparable to EU citizenship, and an examination of the existing legal framework reveals a rather limited conception of the "Civis Eurasiaticus". ${ }^{1}$ Yet the case law of the Eurasian Economic Union Court (EAEU Court) and the interpretative leeway of certain provisions of EAEU law leave space to reflect on potential future developments. Additionally, some inspiration may come from the citizenship provisions of the Russia-Belarus Union state legal framework.

Before we outline the context of free movement in detail it is useful to give a brief overview of the EAEU. The EAEU, active since 2015, was founded by Belarus, the

* University of Fribourg (Switzerland) and Legal Research and Analysis Department, Court of the Eurasian Economic Union (Belarus), respectively. Dr Entin contributed to this article in his personal capacity. The views expressed are his own and do not necessarily reflect the official position of the Court of the Eurasian Economic Union. The authors wish to thank Ekaterina Diyachenko, Dimitry Kochenov and Giovanni Piccirilli for their very useful comments and suggestions, as well as Sabine Cotting for editorial assistance.

1 Opinion of Advocate General Jacobs delivered on 9 December 1992, case C-168/91, Konstantinidis $v$ Stadt Altensteig and Landratsamt Calw, para 46. See also Lenaerts, K. (2012). "Civis Europaeus sum": from the cross-border link to the status of citizen of the Union. In: Cardonnel et al, eds., Constitutionalising the EU judicial system: Essays in honour of Pernilla Lindh. Oxford: Hart Publishing. 
Russian Federation and Kazakhstan and joined by Armenia and Kyrgyzstan. ${ }^{2}$ In terms of institutions, it is far less supranational than the EU.There is a strict hierarchy of institutions from top to bottom: the Supreme Council formed by the heads of EAEU Member States, the Intergovernmental Council formed by the heads of national governments and the Eurasian Economic Commission (ЕЕсомM). The latter consists of a Council formed by the deputy prime ministers and the EECOMM Board composed of ten members nominated as ministers by the Member States, who, however, act independently from the latter as non-political quasicommissioners. While the EЕсомM board can indeed be considered a supranational regulatory body, its decisions are all subject to being cancelled or amended by the Council. ${ }^{3}$ There is no parliamentary assembly at EAEU level.

The EAEU Court, in turn, has a rather limited set of judicial remedies at its disposal compared to the Court of Justice of the European Union (CJEU). ${ }^{4}$ Even though the EAEU Court has given as much effect as possible to the relevant provisions, we cannot overlook the fact that the legal framework offers no real preliminary reference procedure for national courts and, moreover, there is no possibility for the ЕЕСОМ to bring Member States in front of the EAEU Court if they are not in compliance with EAEu law. 5 The EEcomm and Member States can, however, ask the Court for a "clarification" of any provision of EAEU law. Although the advisory opinions of the Court are not formally binding, the Еесомм and Member States tend to comply with them and this instrument has been repeatedly used by both the Еесомм and Member States as a soft substitute for a real sanction in case of a failure to fulfil obligations.

2 On eafu Law development, see, e.g., Dragneva, R., and De Kort, J. (2007). The Legal Regime for Free Trade in the Commonwealth of Independent States. International \& Comparative Law Quarterly 56 (2), pp. 233-266, 266; Cooper, J. (2013). The development of Eurasian economic integration. In: Dragneva and Wolczuk, eds., Eurasian Economic Integration - Law, Policy and Politics. Cheltenham: Edward Elgar; Kembayev, Z. (2016). Regional Integration in Eurasia: The Legal and Political Framework. Review of Central and East European Law 41 (2), pp. 157-194.

3 See for a concise overview Yeliseyeu, A. (2019). The Eurasian Economic Union: Expectations, Challenges and Achievements. German Marshall Fund Policy Paper (10), pp. 1-22, 3-4.

4 For an overview of the competence of the Court see Diyachenko, E. and Entin, K. (2017) The Court of the Eurasian Economic Union: Challenges and Perspectives. Russian Law Journal 5 (2), pp. 53-74. For a detailed analysis of the Statute of the Court provisions see Дьяченко, Е., Энтин, К. (2017) Компетенция Суда ЕАЭС: мифы и реальность. Международное правосудие 3 (23), pp. 76-95.

5 See in detail Entin, K. and Pirker, B. (2018). The early case law of the Eurasian Economic Union Court: On the road to Luxembourg? Maastricht Journal of European and Comparative Law 25 (3), pp. 266-287; Kembayev, Z. (2016). The Court of the Eurasian Economic Union: An Adequate Body for Facilitating Eurasian Integration? Review of Central and East European Law 41 (3-4), pp. 342-367; Исполинов, А. (2016). Статут Суда ЕАЭС как отражение опасений и сомнений государств-членов Евразийского экономического союза. Право. Журнал Высшей школы экономики 4, pp. 152-166. 
The Professional Athletes case ${ }^{6}$ is a perfect example here as it originated from a complaint to the Еесом by the Ministry for International Economic Integration and Reform of Armenia over a perceived violation of the rights of Armenian basketball players as workers in sports clubs of the Russian Federation. In its inquiry, the Eесомm discovered that the Russian Federation had indeed put in place quantitative limits on participation in sports competitions based on players' nationality, differentiating between Russian nationals and nationals of other Member States. The Eесомм adopted a decision ${ }^{7}$ prompting Member States to comply with their obligations under Article 97(2) EAEU Treaty by ensuring equal possibilities for athletes from other Member States to work in sports organisations. The Russian Federation, however, made no move to comply with the EECOMM's decision. It argued that the case did not fall under Article $97(2)$ as the measures were not protectionist (this would be prevented under the Treaty) but rather were part of a policy to promote better conditions for the training of athletes. In response, the ЕЕсом M sought a clarification of the relevant Treaty provision from the Court. On 7 December 2018, the EAEU Court handed down a remarkable advisory opinion that not only qualified measures taken by the Russian Federation as restrictions falling under Article 97(2) EAEU Treaty, but also tackled a number of important issues, such as the horizontal effect of a fundamental freedom, the direct effect and primacy of EAEU Treaty norms, as well as the powers of the EECOMM.

Substantive law includes numerous provisions on free movement covering the free movement of goods ${ }^{8}$ and services, the freedom of establishment as well as the activities of the self-employed. ${ }^{9}$ This chapter focuses on the aspect, which has thus far received most attention, namely freedom of movement for workers. Our aim is to determine to what extent there is an EAEU citizen, and if the latter is a "mere" market citizen ${ }^{10}$ or more.

6 Court of the Eurasian Economic Union, advisory opinion of 7 December 2018, case CE-2-2/ 5-18-BK, Eurasian Economic Commission (Professional Athletes case), para. III.2. Cf. Pirker, B. and Entin, K. (2019). Bosman's Second Life? The Eurasian Economic Union Court and the Free Movement of Professional Athletes. Legal Issues of Economic Integration 46 (2), pp. 129-148, 148; Энтин К. и Дьяченко Е. (2019) Обзор практики Суда Евразийского экономического союза в 2018 году. Международное правосудие 1 (29), pp. 3-22.

$7 \quad$ Decision $\mathrm{n}^{\circ} 47$ of 11 May 2017.

8 Art. 28, 29 EAEU Treaty.

9 Art. 65-69 EAEU Treaty and Protocol No. 16.

10 On the notion see e.g. Everson, M. (1995). The Legacy of the Market Citizen. In: Shaw and More, eds., New Legal Dynamics of European Union. Oxford: Clarendon Press; Wollenschläger, F. (2007). Grundfreiheit ohne Markt: Die Herausbildung der Unionsbürgerschaft im unionsrechtlichen Freizügigkeitsregime. Tübingen: Mohr Siebeck; Nic Shuibhne, N. (2010). The Resilience of EU Market Citizenship. Common Market Law Review 47 (6), pp. 1597-1628; Van Cleynenbreugel, P. (2015). Citizens beyond the market? 


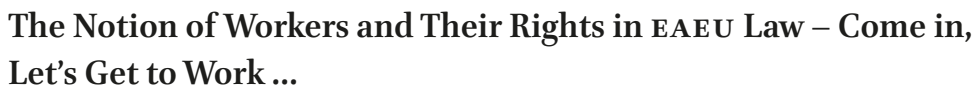

The Notion of Workers and Their Rights in EAEU Law - Come in, Let's Get to Work ...

A number of factors influence the effectiveness of free movement provisions. For the present purpose, we will take into account first the goals of EAEU integration and the effects of EAEU law in the context where it most matters, namely in Member States' legal orders. We then turn to the status of workers and the rights connected to this status, as well as the effects of, and exceptions to, the relevant fundamental freedom of EAEU law. In the first part of this article we focus deliberately on the aspects of the law most favourable to free movement.

\section{The Goals of EAEU Integration and the EAEU Citizen}

At first glance, the objectives of the EAEU Treaty seem to aim mostly at establishing a single market and inter-state cooperation. Article 4 of the EAEU Treaty sets down a number of main objectives for the Union. The provision outlines as its goals the creation of a common market for goods, services, capital and labour within the Union (point 2) as well as the comprehensive modernisation, cooperation and competitiveness of national economies within the global economy (point 3). As the first point, in contrast, the document lists the creation of conditions to encourage sustainable economic development in Member States in order to improve the living standards of their populations. In theory at least, there is no obstacle to adopting a broad reading of the living standards of Member States' populations, and also fostering more opportunities in life for individuals, which could stretch to more extensive rights to free movement. Nonetheless, the improvement of living standards is framed as a goal to be achieved through the tool of sustainable economic development, which emphasizes the need for (sustainable) economic components of the project.

Still, even if some elements of the preamble to the EAEU Treaty also point at a strong role for Member States ${ }^{11}$ and for economic cooperation, ${ }^{12}$ there are also parts that focus on the position of individuals and how the EAEU can further this position. Recital 2 requires "unconditional" respect for the supremacy of constitutional rights and freedoms of "man and national", while recital 3 aims to strengthen solidarity and cooperation between the "peoples" of Member States'.

EU citizenship in the context of European economic and social integration. In: Oliveira Pais, ed., EU Citizenship - Challenges and Opportunities. Porto: Universidade Catolica Editora. 
There is thus a justification for developing a reading of provisions of EAEU law in light of these objectives, giving weight to the protection of the legal position of individuals not only for economic purposes, but also for their own sake as "man and national", as phrased in the Treaty. The EAEU Court has been initially reticent towards this idea, using Article 4 of the EAEU Treaty only to advance the idea of the common market through teleological interpretation. ${ }^{13}$ However, in a recent advisory opinion regarding pensions for EAEU civil servant, ${ }^{14}$ the Court showed its willingness to assume some of the functions of a constitutional court. Referring to the provisions stated in the preamble on the "unconditional respect" for the constitutional rights and freedoms of a "man and national", the court interpreted that provision as follows: "the level of such rights and freedoms guaranteed by the Union shall not be lower than that ensured in the Member States". This is reminiscent of the early case law of the ECJ in Stauder ${ }^{15}$ and Internationale Handelsgesellschaft ${ }^{16}$ and could thus have a significant effect on the free movement of workers. The position of the Court here illustrates its willingness to draw inspiration from the national constitutions in the absence of an EAEU catalogue of fundamental rights, thus creating a sort of a general principle of EAEU law. The phrasing used by the Court also suggests that instead of a minimal standard or common denominator, the Court will be willing to adopt the highest standard of protection that exists among Member States.

\section{$2 \quad$ The Effects of EAEU Law}

Although the Treaty itself provides no such clear indication, through its case law the EAEU Court has established far-reaching effects of EAEU law in the domestic legal orders of Member States. ${ }^{17}$ First, the EAEU Court has determined

13 See, e.g. in the context of competition law, Court of the Eurasian Economic Union, advisory opinion of 4 April 2017, case CE-2-1/1-17-BK, Ministry of Justice of Belarus (Vertical Agreements case), part IV para. 2(5).

14 Court of the Eurasian Economic Union, advisory opinion of 20 December 2018, case CE-22/7-18-BK, Eurasian Economic Commission (Pensions case), section III, para. 3.1. Summary in English available at http://courteurasian.org/page-26491.

15 Court of Justice, judgment of 12 November 1969, case 29/69, Stauder v. Stadt Ulm. Cf. Douglas-Scott, S. (2018). The European Union and Fundamental Rights. In: Schütze and Tridimas, eds., Oxford Principles of European Union Law. Oxford: Oxford University Press, 409-410.

16 Court of Justice, judgment of 17 December 1970, case 11/70, Internationale Handelsgesellschaft.

17 For an overview of the main characteristics of EAEU law see Дьяченко Е. и Энтин К. (2018) Свойства права Евразийского экономического союза сквозь призму практики Суда ЕАЭС. Журнал российского права 10 (262), pp. 123-133. 
that EAEU law can have direct effect. It did so by simply stating in the Vertical Agreements Case ${ }^{18}$ that the provisions of Article 76 containing general rules of competition "had direct effect and shall be applied directly" before setting up the criteria for direct effect in its Opinion on Professional Athletes stating that, where a norm conferred rights on individuals, was sufficiently precise and unconditional and did not require implementation, it possessed direct "effect and applicability". ${ }^{19}$ It thereby overruled sceptical voices in the doctrine. These commentators had argued that the Court was not strong enough as an institution to develop the principle of direct effect and "introduce it to regular practice" 20 or that the lack of a preliminary reference procedure - and the corresponding lack of cooperation between the EAEU Court and national courts would hamper any effective implementation of a direct effect doctrine. ${ }^{21}$

Second, after some early reticence ${ }^{22}$ the EAEU Court embraced primacy in its Advisory Opinion on Downsizing, holding that national legislation could only apply to labour relations within the limits of EAEU law within the latter's scope, and that the point of departure was the primacy of Treaty rules. ${ }^{23}$ However, the exact reasons for these statements on primacy were not clear. In the Opinion on Professional Athletes, the Court cited a question asked by the EЕСOMM to directly address national courts and emphasized that in cases of conflict with national law, it was their duty to be guided by the provisions of EAEU law. ${ }^{24}$ Consequently, and based on the experience of EU law, one can probably legitimately assume that such primacy implies certain obligations for national courts regarding EAEU law, e.g. that courts have to interpret national

18 Court of the Eurasian Economic Union, advisory opinion of 4 April 2017, case CE-2-1/1-17BK, Ministry of Justice of Belarus (Vertical Agreements case), part IV para. 2(1).

19 Court of the Eurasian Economic Union, advisory opinion of 7 December 2018, case CE-22/5-18-BK, Eurasian Economic Commission (Professional Athletes case), para. III.2.

20 Kalinichenko, P. (2017). A Principle of Direct Effect: The Eurasian Economic Union's Court Pushes for More Integration. Verfassungsblog, available at https://verfassungsblog.de.

21 Rosano, A. (2018). Wrong Way to Direct Effect?: Case Note on the Advisory Opinion of the Court of the Eurasian Economic Union Delivered on 4 April 2017 at the Request of the Republic of Belarus. Legal Issues of Economic Integration 45 (2), pp. 211-220, 218.

See the avoidance of an answer in Court of the Eurasian Economic Union, judgments of 28 December 2015, 3 March 2016, cases CE-1-2/2-15-KC and CE-1-2/2-15/AP, Tarasik K.P. v. Eurasian Economic Commission and a rather implicit formula used in Court of the Eurasian Economic Union, judgment of 21 February 2015, case CE-1-1/1-16-BK, Russian Federation v. Republic of Belarus, para. $7(4)$.

23 Court of the Eurasian Economic Union, advisory opinion of 12 September 2017, case CE2-2/1-17-BK, Eurasian Economic Commission, para. 4(7).

24 Court of the Eurasian Economic Union, advisory opinion of 7 December 2018, case CE-22/5-18-BK, Eurasian Economic Commission, para. III.7. 
law as much as possible in conformity with EAEU law but where this is not possible, they have to set its rules aside. ${ }^{25}$ These elements are necessary if we wish to understand that, independent of the scope of a worker's status and rights under EAEU law, EAEU law holds powerful legal effects which can render these norms effective also within the national legal orders of the Member States. ${ }^{26}$

\section{3}

\section{The Definition of a Worker}

One key difference which stands out when comparing the provisions of the EAEU Treaty with those of TFEU is an abundance of definitions. It should be noted here that the authors of the EU Treaties deliberately refrained from giving definitions of notions such as "quantitative restrictions and measures having equivalent effect" or "workers", thus leaving it to the CJEU to fill the gaps. In contrast, the drafters of the EAEU Treaty preferred to avoid surprises and agreed on a set of definitions. In addition to a main list in Article 2 EAEU, each of the chapters and even each of the protocols have its own list of definitions. This approach can be partly explained by the legislative tradition of the EAEU Member States. ${ }^{27}$ Even more importantly, however, the EAEU Treaty can be seen as a codification of a number of existing treaties in the framework of the customs union and the single economic area.

According to Article 96(5) EAEU, to qualify as a worker under EAEU law a person must be "a national of a Member State lawfully residing and lawfully engaged in labour activities in the state of employment, of which he or she is not a national and where he or she does not permanently reside". ${ }^{28}$ Thus, under EAEU law, to be a worker means exercising a labour activity, i.e. an activity

25 Pirker, B. and Entin, K. (2019). Bosman's Second Life, cit., 141.

26 See on the direct effect of the free movement of workers provisions in EU law e.g. Court of Justice, judgment of 15 October 1969, case 15/69, Ugliola. In recent literature see generally e.g. Nihoul, P. (2018). Effet direct et protection des citoyens. In: Paschalidis and Wildemeersch, eds., L'Europe au présent!: liber amicorum Melchior Wathelet. Brussels: Bruylant.

27 See on the role of definitions in Russian law: Таева, Н. (2016). Дефиниции в конституционном законодательстве. Lex Russica 3 (112), pp. 153-163; Вопленко Н., Давыдова М. (2001). Правовые дефиниции в современном российском законодательстве. Вестник Нижегородского государственного университета им. Н.И. Лобачевского 1, pp. 64-71.

28 See on the need for this cross-border element in EU law e.g. Court of Justice, judgment of 16 December 2004, case C-293/03, My, para. 40; in recent literature e.g. Wollenschläger, F. (2015). Binnenmarktrelevanz statt grenzüberschreitender Aktivität - die Rs. Belgacom als Neujustierung in der Dogmatik der Grundfreiheiten. In: Stumpf et al, eds., Privatrecht, Wirtschaftsrecht, Verfassungsrecht - Privatinitiative und Gemeinwohlhorizonte in der europäischen Integration. Baden-Baden: Nomos. 
performed under an employment contract, or to perform works (services) under a civil law contract "in accordance with the legislation" of the relevant Member State.

Compared to CJEU case law such an approach appears to be much more formalistic. The CJEU has recognised that the main feature of an employment relationship is that "for a certain period of time a person performs services for and under the direction of another person in return for which he receives remuneration". ${ }^{29}$ Thus for the CJEU, a person may be considered a worker even without a work contract ${ }^{30}$ provided that they can demonstrate that their activity is "effective and genuine". ${ }^{31}$ The EAEU Court, by contrast, is bound by the definition contained in Article 96(5). Thus, when confronted with the question of whether professional sports are to be considered employment, the Court examined the relevant national laws of the Member States and ascertained that in all Member States, relations between players and professional sport clubs are governed by working contracts. ${ }^{32}$ This, however, should not be misunderstood as a sign that the autonomy of notions of EAEU law was being abandoned which would mean that such notions could be defined by national law in whichever way a Member State sees fit. In EU law, the CJEU similarly partly defers to national definitions, partly imposes limits of EU law on such definitions. ${ }^{33}$ In EAEU law it is currently unclear to what extent in the future the EAEU Court will defer to national definitions or impose limits of EAEU law in certain extreme cases. ${ }^{34}$

The main advantage of the EAEU approach to legal definitions is that it simplifies the work of national courts and limits the discretion of national authorities which do not have the possibility to oppose the validity of a person's rights on the grounds that their work is not genuine or effective. On the other hand,

29 See Court of Justice, judgment of 3 July 198, case 66/85, Lawrie-Blum. Reiterated in judgment of 17 July 2008, case C-94/o7, Raccanelli, para. 33. On the notion(s) of workers in EU law see e.g. Ziegler, K. (2011). Arbeitnehmerbegriffe im Europäischen Arbeitsrecht. Baden-Baden: Nomos.

30 See, for instance, Court of Justice, judgment of 12 February 1974, case $15^{2} / 73$, Sotgiu v. Deutsche Bundespost.

31 See Court of Justice, judgment of 23 March 1982, case 53/81, Levin $v$ Staatssecretaris van Justitie, paras. 17,18 .

32 Court of the Eurasian Economic Union, advisory opinion of 7 December 2018, case CE-22/5-18-BK, Eurasian Economic Commission (Professional Athletes case), para. III.3.

33 See e.g. Court of Justice, judgment of 5 October 2010, case C-40o/10 PPU, $M c B$, para. 52; Court of Justice, judgment of 24 April 2012, case C-571/10, Kamberaj, para. 8o. See generally Pirker B., Entin K. (2019). Legal Issues of Economic Integration, cit, p. 144-145.

34 In the sense of an EAEU law based margin of discretion granted to the Member States in how they define such terms. 
one could argue that this places a heavy emphasis on the legal character of the relevant activities, meaning that those working without the necessary documents are not able to invoke the Treaty provisions.

Another obvious problem with the definition of a "worker" given in the Treaty is that it seems to limit the scope of this term to those who are temporarily residing in the Member State where they are working. Does this mean that once a person obtains the right of permanent residence in a Member State he or she is automatically excluded from the scope of the Treaty? Such a narrow reading seems to clash with the Treaty objectives. Furthermore, the definition of the "state of permanent residence" in Article 96(5) defines that state as the one of the nationality of the relevant worker, effectively equating permanent residence and nationality. Thus, it does not appear that the authors of Treaty intended to exclude a category of people, namely permanent residents, from the scope of the Treaty. Rather, it can be assumed that the emphasis put on the temporary character of residence is meant to underline that the Treaty does not create a right to permanent residence and that Member States are to outline the conditions for obtaining this right in their national legislation. In the EU, by contrast, the right to remain in a Member State after having been employed in that state was introduced as early as 1970 with regard to workers and their family members. ${ }^{35}$ The preamble of the relevant regulation stated that this right represents a corollary to the right of residence acquired by workers in active employment.

Finally, what can be said about cross-border workers? The ECJ had no difficulty in extending the social advantages and the principle of non-discrimination to cross-border workers, including in the field of taxation. ${ }^{36}$ However, a similar step would require considerably more effort from the EAEU Court in order to overcome the inherent limitation of the Treaty definitions.

\section{$4 \quad$ Rights Granted to the Worker}

Once a person is considered a worker under EAEU law, what rights does this confer? Residence and entry rights under the EAEU Treaty are rather limited. The right to residence based on the provisions of EAEU law is bound to

35 See Regulation (EEC) No 1251/70 of the Commission of 29 June 1970 on the right of workers to remain in the territory of a Member State. OJ L 142, 30.6.197o, p. 24-26.

36 See, for instance, Court of Justice, judgment of 14 February 1995, case C-279/93, Schumacker, where the Court interpreted the Treaty provision on the free movement of workers as precluding a provision of national legislation making annual adjustment of deductions at source available only to residents, thereby excluding natural persons who have no permanent residence or usually abode on its territory but receive income there from employment. 
the duration of the employment contract at hand. ${ }^{37}$ There is - somewhat implicitly - a right of entry and the right not to register for the first 30 days in the territory of the state of employment, inasmuch as there is such a requirement to register under national law. ${ }^{38}$ Although the objective of these provisions is not expressly mentioned, it seems that the period of 30 days is meant to allow job seekers to look for work without undertaking additional formalities. One could note that even before the introduction of EU citizenship the right for jobseekers to arrive and stay in a Member State existed in EU law, although the precise duration was not laid down expressly. ${ }^{39}$ In EAEU law, terms of the treaty suggest that entry can only occur "for employment", seemingly precluding them being applied to other purposes of stay. There are, in addition, certain alleviations for Member State nationals entering other Member States for purposes "provided for by the legislation" of that state. ${ }^{40}$

The right to stay in a Member State of employment is prolonged by 15 days if go days have expired since the date of entry of the worker and if an employment contract is terminated early. In that case, the worker can stay only if they enter into a new employment contract within 15 days. ${ }^{41}$ Implicitly, these provisions seem to suggest that the right of residence is otherwise limited to the duration of the employment contract and this impression is further reinforced by the definition of a worker as discussed above.

Access to employment is also facilitated. Based on Article 98(1) EAEU Treaty a worker has the right to engage in professional activities in accordance with his/her specialisation and qualifications, including the right to have relevant degrees and certificates recognised in accordance with the treaty and the

37 Art. 97(5) EAEU Treaty.

38 Art. 97(6) EAEU Treaty. See on such (permissible) requirements Art. 8 Directive 68/36o/ EEC, OJ $1968 \mathrm{~L} 257,13 \mathrm{ff}$., as the predecessor norm before the right of stay for three months was granted without any such requirement by Article 6(1) of Directive 2004/38/EC of the European Parliament and of the Council of 29 April 2004 on the right of citizens of the Union and their family members to move and reside freely within the territory of the Member States, OJ 2004 L 158, $77 \mathrm{ff}$.

39 See on the permissibility of a six-months period Court of Justice, judgment of 26 February 1991, case C-292/89, Antonissen, para. 21.On the end of the status of a worker under EU law generally see e.g. Pirker, B. (2014). Zum Verlust der Arbeitnehmereigenschaft im Freizügigkeitsabkommen. Aktuelle Juristische Praxis 23 (9), pp. 1217-1225.

40 In essence, when a Member State national enters another Member State, normally they have to use a migration card; but if their stay does not exceed 30 days and they use a suitable document for affixing marks of border control authorities, they do not have to use such a card, Art. 97(7) and (8) EAEU Treaty. 
legislation of the employment state. ${ }^{42}$ Employers may hire workers from other Member States without considering restrictions for the protection of the national labour market; workers must not be required to obtain employment permits. ${ }^{43}$

Workers also have protections once employed. With regard to social security, workers have a right to non-discrimination vis-à-vis nationals of the state where they are employed although pensions are excluded and are instead governed by the legislation of the state of permanent residence and by a separate international treaty between the Member States. ${ }^{44}$ Such a treaty, the Agreement on the provision of pensions for workers, has been signed during a meeting of the Supreme Council in St Petersburg in December 2019 but has not entered into force yet. The agreement grants workers the same status as nationals with regard to the conditions for fixing and paying pensions and the possibility to export some of their pension rights. This will allow workers to have their work experience abroad counted and grant them the possibility to receive their pension in another state.

Workers' rights to emergency medical care and other types of medical treatment are also regulated partly in the Treaty, partly by the legislation of the country where they are employed and partly by applicable international treaties. ${ }^{45}$

Workers are entitled to receive information on the conditions of their stay and employment and their rights and obligations as provided by the legislation of the country where they are employed, both from the state and the employer as the addressee. ${ }^{46}$ Upon request, workers are also entitled to a certificate from the employer indicating their profession and position(s), the period of employment and wages as determined by the legislation of the state of employment. ${ }^{47}$

Which measures fall within the scope of the legal protections that workers enjoy under EAEU law? The EAEU Court had the opportunity to interpret the law in the Professional Athletes case. Based on its earlier definition of a

42 See also Art. 97(3) EAEU Treaty. See in EU law Directive 2005/36/EC, OJ 2005 L 255, 22 ff., and in the case law: Court of Justice, judgment of 7 May 1991, case C-340/89, Vlassopoulou, para 14. In the literature, see e.g. Claessens, S. and Schneider, H. (2005). The Recognition of Diplomas and the Free Movement of Professionals in the European Union. In: Schneider, ed., Migration, Integration and Citizenship. Maastricht: Forum; Gammenthaler, N. (2010). Diplomanerkennung und Freizügigkeit. Zurich/Basel/Genf: Schulthess.

43 Art. 97(1) EAEU Treaty.

44 Art. 98(3) EAEU Treaty.

45 Art. 98(4) EAEU Treaty.

46 Art. 98(6) EAEU Treaty.

47 Art. 98(7) EAEU Treaty. 
worker, the Court held that restrictions would fall within the scope of the Treaty if they affected the employment activity of the people in question. ${ }^{48}$ In the context of sports, this meant that restrictions concerning sporting matters exclusively seemed not to fall within the Treaty. ${ }^{49} \mathrm{~A}$ classic example would be rules on the composition of national teams that should not be affected by EAEU law. ${ }^{50}$

When asked what kind of measures fell within this scope, the EAEU Court decided based on the indicative wording of the Treaty, but also based on inspiration from the CJEU's case law, ${ }^{51}$ that restrictions as well as discriminatory measures could be scrutinised under the Treaty. For the Court, restrictions were defined as measures which preclude or deter the nationals of EAEU Member States from exercising their right to work in another Member State, including working conditions, ${ }^{52}$ but also e.g. access restrictions influencing employment prospects or residence-based restrictions. ${ }^{53}$

\section{$5 \quad$ Horizontal Effect, Mutual Recognition and Mutual Trust}

To some extent at least, the fundamental freedom of movement of workers also has a horizontal effect. In the Professional Athletes case, the EAEU Court found that Articles 97(1) and (2) EAEU Treaty were not only applicable to State authorities, but also to sports organizations as the employers of professional athletes. Restrictions could thus be laws, acts below the level of a law or local acts of

48 Court of the Eurasian Economic Union, advisory opinion of 7 December 2018, case CE-22/5-18-BK, Eurasian Economic Commission (Professional Athletes case), para. III.3. Whereas the text of Article $45 \mathrm{TFEU}$ points in the direction of a prohibition of discrimination, the CJEU has clarified through its case law that both restrictions and discriminatory measures are covered by the provision, see e.g. Court of Justice, judgment of 17 March 2005, case C-109/o4, Kranemann, paras. 25-26.

49 See for such a restrictive approach also the earlier case law of the cJEU, e.g. Court of Justice, judgment of 12 December 1974, case 36/74, Walrave and Koch, para. 4. In its later case law, the Court narrowed down this exception and seems to perceive most restrictions concerning sporting matters as also falling within the scope of the Treaty, although they can be justified on legitimate reasons if they are proportionate, see e.g. Court of Justice, judgment of 11 April 2000, case C-51/96, Deliège, para. 43. See also Muresan, R. (2010). Ausnahmen von den EU-Grundfreiheiten im Bereich des Sports nach der "Deliège"Konzeption. Basel: Helbing Lichtenhahn.

$50 \quad$ Pirker, B. and Entin, K. (2019). Bosman's Second Life, cit., 138.

$5^{1}$ Court of Justice, judgment of 15 December 1995, case C-415/93, Bosman, para. 96.

52 See in EU law Art. 7(1) and (2) Regulation 492/11 on "conditions of employment and work" and "social and tax advantages".

53 Court of the Eurasian Economic Union, advisory opinion of 7 December 2018, case CE-2-2/5-18-BK, Eurasian Economic Commission (Professional Athletes case), para. III.4. Compare this to EU law's rules in Regulation 492/2011, OJ 2011 L 141, p. $1 \mathrm{ff}$. 
responsible organizations. ${ }^{54}$ If we compare this to the situation in EU law, at least for now the EAEU Court has not gone as far as the CJEU in relation to the free movement of workers, as the latter has established far-reaching horizontal effect for private employers in relation to discriminatory measures. ${ }^{55}$ The approach of the EAEU Court is, however, comparable to the CJEU's in relation to other fundamental freedoms, where the latter court similarly focused on private actors with a certain collective regulatory power. ${ }^{56}$ There also does not seem to be any obvious reason why the EAEU Court could not follow a similar reasoning to that of the CJEU, namely deciding that without such an effect, private obstacles could be re-established where Member State measures have been struck down. ${ }^{57}$

Traces of mutual recognition and mutual trust can also be detected in the EAEU Court's case law on other fundamental freedoms, for example in a case where customs authorities were required under EAEU law to refrain from taking unilateral decisions on documents issued by the authorities of another Member State. ${ }^{58}$

\section{$6 \quad$ Exceptions to the Free Movement of Persons in EAEU Law}

Art. 97(2) EAEU Treaty prescribes strict limits regarding the exceptions to free movement provisions. Member State measures must be aimed at ensuring national security including in economic sectors of strategic importance and public order. In its relevant case law, the Court remained rather succinct..$^{59}$ Note, nonetheless, that the list of possible restrictions in the Treaty is shorter and unlike EU law does not mention public health. ${ }^{60}$ Nothing seems to preclude the EAEU Court from engaging in an exercise similar to that of the CJEU and the

54 Court of the Eurasian Economic Union, advisory opinion of 7 December 2018, case CE-22/5-18-BK, Eurasian Economic Commission (Professional Athletes case), para. III.5.

55 Court of Justice, judgment of 6 June 200o, case C-281/98, Angonese.

56 Court of Justice, judgment of 12 December 1974, case 36/74, Walrave; judgment of 12 July 2012, case C-171/11, Fra.bo; judgment of 11 December 2007, case C-438/05, Viking; judgment of 18 December 2007, case C-341/05, Laval. On the debate over the horizontal effect of fundamental freedoms and its variations in the case law in EU law see e.g. Müller-Graff, P.-C. (2014). Die horizontale Direktwirkung der Grundfreiheiten. Europarecht 16 (1), pp. 3-29; Kainer, F. (2015). Die Gewährleistung von Privatautonomie im Spannungsfeld horizontaler Wirkung von Grundfreiheiten und Grundrechten in der Europäischen Union: Eine Skizze. In: Stumpf et al, eds., Privatrecht, Wirtschaftsrecht, Verfassungsrecht - Privatinitiative und Gemeinwohlhorizonte in der europäischen Integration. Baden-Baden: Nomos.

57 Court of Justice, judgment of 16 March 2010, case C-325/o8, Olympique Lyonnais, para. 31.

58 Court of the Eurasian Economic Union, judgment of 21 February 2015, case CE-1-1/1-16-BK, Russian Federation v. Republic of Belarus, para. 3(5).

59 Court of the Eurasian Economic Union, advisory Opinion of 7 December 2018, case CE-22/5-18-BK, Eurasian Economic Commission (Professional Athletes case), para. III.5.

6o Se e.g. in EU law Court of Justice, judgment of 13 April 2010, case C-73/o8, Bressol, para. 55 . 
EU legislature in precisely outlining the possible grounds for (and elements to be taken into account in) expulsion decisions, for example. ${ }^{61}$ The inclusion of "economic sectors of strategic importance" in the concept of public security, however, is rather puzzling. While the EU has settled case law stating that Member States are allowed to restrict the admission of foreign nationals to certain activities in public services, ${ }^{62}$ the term 'economic sectors of strategic importance' is extremely broad and seems to leave a wide margin of discretion for the EAEU Member States when determining such spheres. In this situation it will be up to the ЕЕсомм and the Court to prevent possible abuses by requiring Member States to demonstrate a genuine link between the chosen economic sector and national security. One possible example could be the energy field where a direct link between energy and security has been established in CJEU case law on the free movement of goods. ${ }^{63}$ Safeguarding a secure energy supply in case of a crisis has also been recognized as a ground of public security by the ECJ in the well-known "golden shares" cases. ${ }^{64}$

More extensive reasoning on exceptions to fundamental freedoms enshrined in the EAEU Treaty can be borrowed from the context of the free movement of goods. Faced with a case on Article 29(1) and (3) of the Treaty, the EAEU Court

61 See in EU law with regard to EU citizens Articles 27 to 29 Directive 2004/38; in the (comprehensive) jurisprudence see Court of Justice, judgment of 4 December 1974, case 41/ 74, Van Duyn; judgment of 28 October 1975, case $36 / 75$, Rutili; judgment of 27 October 1977, case 30/77, Bouchereau; judgment of 19 January 1999, case C-348/96, Calfa; judgment of 29 April 2004, cases C-482/o1 and C-493/o1, Orfanopoulos; judgment of 23 November 2010, case C-145/og, Tsakouridis; judgment of 22 May 201, case C-348/og, P.I. v. Oberbürgermeisterin der Stadt Remscheid. See also e.g. Kochenov, D. and Pirker, B. (2013). Deporting the Citizens within the Union? A Counter-Intuitive Trend in Case C-348/og, P.I. v. Oberbürgermeisterin der Stadt Remscheid. Columbia Journal of European Law pp. 369-39o; Meduna, M. (2017). "Scelestus europeus sum": what protection against expulsion does EU citizenship offer to European offenders? In: Kochenov, ed., EU Citizenship and Federalism. Cambridge: Cambridge University Press.

62 See, for instance, Court of Justice, judgment of 12 February 1974, case 152/73, Sotgiu.

63 See Court of Justice, judgment of 10 July 1984, case $72 / 83$, Campus Oil. For a broader reflection in this context see Leal-Arcas, R. and Filis, A. (2013). Conceptualizing EU energy security through an EU constitutional law perspective. Fordham International Law Journal 36 (5), pp. 1225-1301.

64 See Court of Justice, judgment of 10 November 2011, case C-212/o9, Commission v. Portugal; judgment of 4 June 2002, case C-503/99, Commission v. Belgium. In the literature, see Gallo, D. (2018). On the content and scope of national and European solidarity under free movement rules: The case of golden shares and sovereign investments. In: Biondi et al, eds., Solidarity in EU Law - Legal Principle in the Making. Cheltenham: Edward Elgar; Apel, M. (2017). Golden Shares: Eine rechtsdogmatische Untersuchung der primärrechtlichen Zulässigkeit regulatorischer sowie privater Sonderrechte an Unternehmen unter Berücksichtigung der Rechtsökonomik. Baden-Baden: Nomos. 
developed its reasoning in that context. Article 29 of the EAEU Treaty is similar to Article 36 of the TFEU and allows Member States to impose restrictions on mutual trade for the protection of fundamental interests such as human life and health, public morals and public order or the environment, provided that such restrictions do not constitute a means of arbitrary discrimination or a disguised restriction on trade between Member States. The EAEU Court took inspiration from CJEU case law ${ }^{65}$ and held that Member States could indeed impose such restrictions, but that their discretion was limited. First, the measures they adopted had to pursue one of the interests laid down in Article 29(1) and these interests had to be narrowly interpreted as exceptions to the principle of free movement. Second, the EAEU Court repeated that restrictions could not constitute arbitrary discrimination or a disguised restriction on trade and held that they had to be proportionate. ${ }^{66}$ Proportionality has also made its appearance in other situations, ${ }^{67}$ which might lead one to wonder whether we are witnessing the emergence of a general principle of the EAEU legal order. ${ }^{68}$

Moreover, some clues can also be taken from case law on the free movement of workers. The EAEU Court reaffirmed that government measures need to be proportionate, i.e. they should facilitate the achievement of the objectives provided in Article 97(2) EAEU and should be limited to actions which are necessary for the achievement of such objectives. ${ }^{69}$ While the Court did not expressly address the possibility of using justifications not explicitly laid down in the Treaty, the jurisprudence of the CJEU which it cited $^{70}$ seems to indicate that the EAEU Court would be willing to accept justifications based on the social function of sports ${ }^{71}$ - though probably not in the case of discriminatory measures. ${ }^{72}$ Such an approach would be preferable to simply excluding different

65 Court of Justice, judgment of 25 January 1977, case 46/76, Bauhuis; Judgment of 20 May 1976, case 104/75, de Peijper.

66 Court of the Eurasian Economic Union, advisory opinion of 30 October 2017, case CE-2-2/ 2-17-BK, Eurasian Economic Commission (Free Movement of Goods Restrictions).

67 Court of the Eurasian Economic Union, advisory opinion of 7 December 2018, case CE-22/5-18-BK, Ministry of national economy of Kazakhstan (Movement of Currency across the EAEU Customs Border), para. IV.7.

68 Pirker B., Entin K. (2019). Legal Issues of Economic Integration, cit, p. 147.

69 Court of the Eurasian Economic Union, advisory opinion of 7 December 2018, case CE-22/5-18-BK, Eurasian Economic Commission (Professional Athletes case), para III.5.

70 Court of Justice, judgment of 15 December 1995, case C-415/93, Bosman; judgment of 16 March 2010, case C-325/o8, Olympique Lyonnais.

$71 \quad$ For instance, the objective of recruiting and training young players.

72 See for this approach in EU law e.g. Court of Justice, judgment of 26 May 2016, case C-30o/ 15, Kohll and Kohll-Schlesser, para. 49. 
rules from the scope of the Treaty since it would allow the Court to have more room for manoeuvre through the application of the proportionality test.

All in all, we can see that, despite obvious similarities between EU and EAEU law many questions remain, notably regarding the concept of "economic sectors of strategic importance" and the possibility of using grounds of justification other than those laid down in the Treaties.

\section{$7 \quad$ Interim Conclusion}

So far, so good? At first glance, EAEU law does not seem very different from the EU legal regime, at least in the case of workers. EAEU law has broad goals that could accommodate interpretations furthering the position of a "Civis Eurasiaticus" under EAEU law; it has potential direct effect and is vested with primacy towards national law. Although the definition of a worker contains some inherent limitations, nothing prevents the EAEU Court from interpreting the concept broadly in order to establish an ultimately autonomous definition in EAEU law and fend off national attempts to undermine EAEU law's effectiveness with competing, narrow definitions. The bundle of rights granted to those who hold the status of a worker will sound familiar to an EU lawyer's ear. Even though rights of entry and residence are very closely linked to employment contracts, a worker will be protected through non-discrimination obligations while only measures justified by important public interests in a proportionate manner may restrict access to employment and employment conditions. We can thus ask whether the "Eurasiaticus" status is thus simply the reduced "Homo Oeconomicus" version of the status of the "Civis Europaeus". Or, in other words, is this the pre-citizenship market citizen without any of the political ambitions surrounding the EU citizenship project?

IV

\section{The Status of Family Members of a Worker - ... You May Bring Your Family, Get Comfortable ...}

Now if we accept that the status of EAEU workers somewhat resembles that of workers in EU law before the advent of EU citizenship, the provisions for the family members of workers are also somewhat logical given the story told so far. Namely, there are a number of protections that ensure that at least some relatives of a worker can come with him or her.

Regarding the definition, family members are defined as the spouse of a worker, their dependent children and other members of their families. To define these other family members, EAEU law refers to such persons being recognised as members of the family according to the legislation of the country 
of employment. ${ }^{73}$ One may wonder how broad or narrow the designation of the circle of beneficiaries could be made by Member States following this delegation rule. Merely based on the wording, national legislation appears to be free to not define any additional family members who would then enjoy rights under EAEU law. Nonetheless, if we take into account the individual rightsfriendly preamble of the Treaty, there is also good reason to favour an obligation of Member States to define family members under EAEU law based on the required "unconditional" respect for constitutional rights and freedoms, which could be read as including e.g. a right to family life.

There is also no indication as to the nationality of family members, meaning that third country nationals can also enjoy the protections of EAEU law as family members. ${ }^{74}$ When they fall within the definition, family members have the same rights of entry and residence as the worker in question. ${ }^{75}$ The express requirement to register after 30 days if so provided by national law is also applicable to family members. Family members of a worker also have the same status as a worker with regard to the right to property and to free transfer of funds, social security and emergency medical care mentioned above. ${ }^{76}$ Children of a worker residing with that worker have the right to attend pre-school institutions and receive education. ${ }^{77}$ The question is left open as to whether they can also rely on the protection of the worker from discrimination with regard to working conditions such as social advantages. ${ }^{78}$ Notably, there is also

73 Art. 96(5) EAEU Treaty.

74 This silence leaves open, however, also certain questions that have come up in EU law. E.g., the CJEU had to decide (and reverse earlier case law) that a third country national does not have to reside legally in an EU Member State before relying on his or her rights of entry and residence under EU law, Court of Justice, judgment of 25 July 2008, case C-127/ o8, Metock, para. 54. In EU law, see also generally Berneri, C. (2017). Family reunification in the EU: the movement and residence rights of third country national family members of EU citizens. Oxford: Hart Publishing.

75 Art. 97(6) EAEU Treaty.

76 Art. 98(2), (3) and (4) EAEU Treaty.

77 Art. 98(8) EAEU Treaty. If we take EU law as guidance, this includes professional education, see Article 10 Regulation 492/2011. According to the CJEU, this access to education must not be restricted merely to those under 21 years of age or to children for whom a worker provides, Court of Justice, judgment of 4 May 1995, case C-7/94, Gaal, para. 25. In EU law, see also Gori, G. (2017). Mademoiselle Gravier and equal access to education: success and boundaries of European integration. In: Fernanda and Davies, eds., EU Law Stories. Cambridge: Cambridge University Press.

78 In EU law at least, the CJEU moved from an earlier negative stance (Court of Justice, judgment of 11 April 1973, case 76/72, Michel S., paras. 6 and 10) towards a positive stance (Court of Justice, judgment ofi6 December 1976, case 63/76, Inzirillo, paras. 18 and 21), arguing that to not grant this possibility would hinder the free movement of the worker if the host 
no specific worker status under EAEU law for persons as family members in the Treaty. ${ }^{79}$

In sum, EAEU law takes a broadly similar approach to EU law. It defines a core group of family members and provides them with somewhat parallel protections to the worker whose family they are a part of. In numerous respects, it does not go as far as EU law. Overall, it seems to pursue, however, an idea similar to EU law that the right to family is part of a worker's legal protections in the context of free movement. The fact that EAEU law contains these explicit provisions can be read as a further indication that a broad, rights-based reading of the legal regime as a whole is both possible and plausible. ${ }^{80}$

\section{The Limitations of the EAEU Worker Status - ... but Not Too Comfortable!}

Of course, in any story as linear as the present one there must come a twist. So far we have noted quite a remarkable convergence between EAEU law and the early stages of EU law concerning the free movement of workers before the advent of EU citizenship, but we now need to take into account certain differences.

The Obligation to Respect the "Culture and Tradition" of the Member State

The first element of difference is that under EAEU law, the position of a worker is not only defined by its rights. Article 98 is named "rights and obligations of a worker". An express provision of the Treaty requires workers and their family members to comply with the legislation of their country of employment, respect the "culture and tradition" of that state and be liable for offences under the latter's legislation. ${ }^{81}$ The first and the last point seem somewhat

Member State could thereby deny family members the social advantages it grants to its own citizens (Court of Justice, judgment of 20 June 1985, case 94/84 ONEM, para. 23).

79 Like in EU law, this is mostly relevant for third country family members, as EAEU citizens can themselves rely on the Treaty protections as workers if they fulfil the necessary conditions, see in EU law Article 23 Directive 2004/38.

80 On the complex relationship between citizenship and (fundamental) rights in the EU context see in recent literature e.g. van den Brink, M. (2019). EU citizenship and (fundamental) rights: Empirical, normative, and conceptual problems. European Law Journal 25 (1), pp. 21-36; Yong, A. (2019). The Rise and Decline of Fundamental Rights in EU Citizenship. Oxford: Hart Publishing.

81 Art. 98(9) EAEU Treaty. 
superfluous, as the EAEU Treaty does not exempt EAEU workers and their family members from compliance with national law nor national criminal law jurisdiction, unless there is a conflict with EAEU law in which case the primacy of the latter applies.

With regard to the second point of Article 98, it remains questionable to what extent binding legal obligations can be distilled from this vague phrase in daily legal practice. However, such obligations do not appear unthinkable. In particular, one could ask whether this clause can be read as a restriction of rights granted by EAEU law. We have only to think of cases where workers are to be expelled, for example because of criminal offences that they have committed. ${ }^{82}$ Crimes seen as violations of particularly important values of the culture and tradition of a Member State could thus be treated as particularly virulent threats to public order and security, and facilitate a path to expelling EAEU workers. The vagueness of the provision is thus disconcerting in light of such potentially far-reaching effects. How could an individual predict what crimes would be covered, and thus fully appreciate the possible consequences of wrongdoing? Moreover, even beyond the scope of EAEU law Member States may feel encouraged by the "culture and tradition" clause to restrict EAEU citizens' legal position in areas where they are free to regulate as they see fit.

\section{2}

\section{The Non-Integration Rationale of the Free Movement of Workers under EAEU Law}

While somewhat disconcerting, the "culture and tradition" clause is not the most striking limitation to the rights and status of an EAEU worker. There is no sign of anything comparable to the right of permanent residence introduced in EU law by Directive 2004/3 $8^{83}$ or even its precursors which granted the right of permanent residence in certain constellations for workers remaining in the territory of a Member State after having been employed in that State. ${ }^{84}$ Rather, Article 96(5) EAEU Treaty provides as part of the definition of an EAEU worker that such a worker must be lawfully residing in the state of employment, but must not permanently reside there.

What EAEU law does here therefore seems to be an equation between the citizenship of a Member State and permanent residence in that state. As shown above, in doing so it does not seem that the intent of those who drafted the EAEU Treaty was to deny workers permanently residing in a Member State the rights guaranteed by the Treaty, although this might be the impression given

\footnotetext{
$82 \quad$ See on this point in more detail section III.6.

83 Article 16 Directive 2004/38.

84 Article 2 Regulation 1251/70 and now Article 17 Directive 2004/38.
} 
by the Treaty at a quick glance. This view is seemingly shared by the EAEU Court, for in the Professional Athletes case the Court did not limit its findings to the players who are not permanently residing in the state of employment. However, the choice of words here was particularly unfortunate as it makes clear that, like the modalities of granting and revoking citizenship, the regulation of permanent residence also remains part of the exclusive competence of the Member States. The latter are hence free to provide the right to permanent residence after a certain amount of time, often based on bilateral agreements between Member States, or to deny such a right altogether. Effectively this means that neither the Еесом $\mathrm{M}$ through its decisions, nor Member States by way of an international agreement within the Union, will be able to provide such a right for workers since this would automatically clash with the provisions of the EAEU Treaty.

This approach appears to be particularly antagonistic towards integration: the goal is to allow the free movement of workers, but without the prospect of gaining permanent residence. At the same time, it appears to be the exact opposite approach to how EU citizenship has evolved more recently. In EU law, by contrast, the CJEU found that even the regulation of the acquisition and loss of national citizenship were within the scope of EU law ${ }^{85}$ and that certain EU citizenship rights gained based on the exercise of free movement could even be retained after an EU citizen has been naturalized in his/her host Member State. ${ }^{86}$

In light of this, the purpose of the protections granted to family members is difficult to explain based on this non-integration rationale of EAEU law. The fact that it is impossible to truly become part of the society of the Member State through a permanently settled residence status is clearly counter to the rights of family members to join the EAEU worker, to receive education and so forth, as their presence arguably reinforces the need to provide for some perspective of permanent integration into the host EAEU Member State.

Moreover, the requirement that workers respect the culture and traditions of their host nation must also be read in conjunction with the lack of an integration rationale of the status of EAEU workers. If EAEU law offers no prospect

85 Court of Justice, judgment of 2 March 2010, Case C-135/o8, Rottmann; Judgment of 12 March 2019, case C-221/17, Tjebbes. For a skeptical assessment of the latter case, see Kochenov, D. (2019). The Tjebbes Fail. European Papers 4 (1), pp. 319-336.

86 Court of Justice, judgment of 14 November 2017, case C-165/16, Lounes. For a discussion of the case see e.g. Réveillère, V. (2018). Family rights for naturalized EU citizens: Lounes: case C-165/16, Toufik Lounes v. Secretary of State for the Home Department, EU:C:2017:862, judgment of the Court of Justice (Grand Chamber) of 14 November 2017. Common Market Law Review 55 (6), pp. 1855-1878. See also the chapter by David de Groot in this volume. 
of permanent residence, this respect clause can hardly be understood as an encouragement to truly engage with or integrate into the culture and tradition of the state of employment. Rather, it seems to subordinate the EAEU worker's own culture and tradition and to cement the idea that under EAEU law, a transitional worker is not here to stay. Integration of such workers and their engagement with the local tradition and culture seems to be perceived thus rather as a threat than as desirable in any true sense of the term.

VI

\section{The (Long and Winding) Alternative Road towards Citizenship: the Experience of the Citizenship of the "Union state" of Russia- Belarus as a Source of Hope?}

Rather than conclude on such a sombre note, an excursion into a related field of law can shed some additional light on the topic of free movement rights in the larger EAEU context. A somewhat limited attempt to create a supranational citizenship has taken place within the framework of the "Union state" of Russia-Belarus. ${ }^{87}$ The Treaty on the creation of a "Union state" was concluded in December 1999 and came into force on January 26, 2000.88 It proclaimed "a new stage in the process of the unification of the peoples of the two countries". Article 6 of the treaty states that Member states, while voluntarily vesting some powers into the Union State, shall retain sovereignty, independence, territorial integrity, state structure, their constitution, state flags, coats of arms, and other attributes of statehood.

Chapter 2 of the Treaty is devoted to Union citizenship. Article 14(1) proclaims that the citizens of one of the Member States are at the same time citizens of the Union state. It thus establishes a direct link between national and Union citizenship, an impression further reinforced by the statements that it is impossible to become a citizen of the Union state without obtaining the citizenship of one of the Member States. ${ }^{89}$ The provisions referring to citizens' rights are not very detailed as from the start the parties were committed to adopting further legal acts in that regard. ${ }^{90}$ Article 14(5) proclaims the

87 For a detailed analysis see Смирнова, Е. (2014). "Гражданство Союзного государст ва Беларуси и России во временном контексте: заявление о намерении или перс пектива реальной интеграции?" - рассуждение правоведа в аспекте региональной компаративистики. Евразийский юридический журнал. 5 (72), pp. 34-39.

88 Treaty on the establishment of the Union State, Moscow 8 December 1999, 2121UNTS 13.

89 Article 14(4) of the Treaty on the Union state.

9o Article $14(6)$ of the Treaty on the Union state. 
principle of equality with respect to citizens' rights and obligations, which is highly reminiscent of Article $9 \mathrm{TEU}$. The effectiveness of this principle, however, appears rather limited since it is not further reinforced by a general prohibition of discrimination on the grounds of nationality. ${ }^{91}$ This principle was further developed in two separate legal acts. The first is a 1996 decision of the Supreme Council of the Belarus and Russia Community on workers' rights which proclaims that workers enjoy equal rights with regard to remuneration, working time and rest, working conditions and work protection as well as other issues of work relations. ${ }^{92}$ In this regard the Union state basically paved the way for the regulation that was created in the framework of the EAEU. Contrary to what some authors assume, ${ }^{93}$ it does not seem that Russian workers in Belarus and workers from Belarus in Russia enjoy any privileged status or possess any additional rights as compared to other Member States' nationals. The second is a 2006 treaty guaranteeing equal rights to the citizens of the Russian Federation and the Republic of Belarus regarding free movement and free choice of temporary and permanent residence on the territory of the Union state's members (hereafter - St. Petersburg Treaty). The St. Petersburg Treaty provides that citizens are allowed to stay in the host state for up to 90 days without registration ${ }^{94}$ and gives them the possibility to directly apply for a permanent residence permit without needing to take on temporary residence status first. ${ }^{95}$ This seems quite advanced even compared to EU law. ${ }^{96}$ The list of restrictions to the rights of free movement and free choice of a place for temporary or permanent residence is, however, wider than in either EU or EAEU law and alongside the traditional grounds of public security, public order, public health and public morality it also includes the necessity to "protect the rights and freedoms of the citizens". ${ }^{97}$

The treaty on the Union state also includes some political rights including the right to elect and be elected in the Parliament of the Union state and to work in the Union states bodies. ${ }^{98}$ What is even more interesting is a clause

91 Similar to Art. 18 TFEU.

92 Decision No.4 of 22 June 1996 "On equal rights of the citizens with regard to access to work, remuneration and other social work-related guarantees", para 2.

93 See Абдуллаев, Э. (2016). Особенности правового регулирования трудовой миграции в странах ЕАЭС на современном этапе, Современная научная мысль 2, pp. 217-224, 223 .

94 Art. 3 of the St. Petersburg treaty.

95 Art. 4 of the St. Petersburg treaty.

96 Art.16(1) of Directive 2004/38 grants a right of permanent residence for Union citizens who have resided legally for a continuous period of five years in the host Member State.

97 Art. 5 of the St. Petersburg treaty.

98 Art. 14(7) of the Union state treaty. 
on mutual diplomatic and consular protection of the Union citizens in third countries. ${ }^{99}$

Thus, the Union citizenship falls short of granting citizens a general right to nondiscrimination and essentially contains similar provisions to EAEU law in relation to workers. However, it also contains some important rights with regard to free movement including the possibility to directly apply for a permanent residence permit based solely on one's citizenship. It remains to be seen whether these provisions could be used as a source of inspiration for the EAEU. So far, given the purely economic focus of the EAEU and the unwillingness of the Member States to move in the direction of a political union, such an evolution seems unlikely.

Another hypothesis could be that of a gradual spill-over. As some authors have pointed out, in many ways the Maastricht Treaty and the Citizens' Rights Directive represented a de facto codification of pre-existing case law. In this regard it has been argued that "a citizenship-like status represented a natural spill-over accompanying the maturation of the internal market". ${ }^{100}$ Would such a spill-over and an emergence of a quasi-citizenship be possible for the EAEU? The inclusion of certain rights for economically inactive migrants like family members and job seekers certainly seem like steps in this direction. On the other hand, these advances are mostly negated by the non-integration logic of the EAEU Treaty which tends to view workers merely as a factor of production and does not even go as far as granting them a right to permanent residence. Most importantly, when analysing the pre-Maastricht quasi-citizenship one cannot ignore the fundamental role played by the Court of Justice whose case law largely contributed to moving lines. Could the EAEU Court follow the same route and, relying on teleological interpretation, contribute to gradually moving lines? The Professional Athletes case certainly demonstrated its willingness to do so. However, without a preliminary reference procedure and without a locus standi for physical persons in annulment actions, it seems highly unlikely that the Court will be able to accumulate a significant amount of case law to trigger such a spill-over.

\section{Conclusion}

In light of all that we have seen, what does it mean if a citizen of one of the EAEU Member States were to exclaim "Civis Eurasiaticus sum"? Given the above,

99 Similar to Art. $20(2) \mathrm{c}$ and 23 TEU Treaty and Art. 46 of the EU Charter of Fundamental Rights.

100 Kochenov, D. and Plender, R. (2012). EU Citizenship: From an Incipient Form to an Incipient Substance? The Discovery of the Treaty Text. European Law Review 37 (4), pp. 369-396, 373 . 
the vision underlying EAEU law's legal framework seems to be fairly limited. In essence, you can work in another EAEU Member State, be protected from unjustified restrictions and discrimination, bring your family with you and enjoy some protections that appear a bit unclear as to their content and scope. By contrast, you are not supposed to permanently settle in a foreign country under EAEU law, and your right to residence is very tightly linked to your employment contract. In contrast to EU law, where even before the advent of EU citizenship, the status of workers went beyond such narrow confines, EAEU law seems to adhere to a very narrow "Homo Oeconomicus" perspective with regard to "its" citizens. Or at least, that is the story so far. As shown throughout this chapter, the protections of EAEU law do offer some "wiggle-room". In particular, nothing excludes - and some elements promote - a broader, more rights-based reading of the law, including the right to family life. Much will thus depend on the interpretative evolution of the EAEU legal order, through the case law of the EAEU Court, and also of national courts. Some inspiration may also be found in the citizenship provisions of the Russia-Belarus Union state legal framework. As in the case of EU citizenship, the prevailing vagueness and interpretive leeway may sometimes eventually work to the benefit of EAEU citizens, and sometimes to their disadvantage. However, in light of the earlier willingness of the EAEU Court to look in the direction of EU law, it is hopefully not wrong to expect at least some "citizenship spirit" in the jurisprudence to come. 
Benedikt Pirker and Kirill Entin - 9789004433076 Downloaded from Brill.come4/26/2023 03:02:58PM via free access 